\title{
Em busca do edifício escolar: contributo para a História Local da Educação (freguesia de S. Vicente de Pereira, Ovar, 1888-1892)
}

In search of the school building: contribution to the Local History of Education (S. Vicente de Pereira parish, Ovar, 1888-1892)

En busca del edificio escolar: contribución a la Historia Local de la Educación (parroquia de S. Vicente de Pereira, Ovar, 1888-1892)

\author{
Wenceslau Gonçalves Neto \\ Universidade de Uberaba; Universidade Federal de Uberlândia (Brasil) \\ Bolsista Produtividade em Pesquisa do CNPq \\ Beneficiário do Programa Pesquisador Mineiro da Fapemig \\ http://lattes.cnpq.br/6258906373771462 \\ https://orcid.org/0000-0002-4374-0311 \\ wenceslau@ufu.br \\ Justino Pereira de Magalhães \\ Universidade de Lisboa (Portugal) \\ https://orcid.org/0000-0001-9464-6782 \\ justinomagalhaes@ie.ulisboa.pt
}

\section{Resumo}

O texto incide sobre tema menos esclarecido na História da Educação em Portugal - o estatuto educacional da freguesia no contexto da oferta escolar. A freguesia constituiu a instância geográfica, administrativa e social de alfabetização escolar. É um estudo de micro-história, porventura de "pequena história", mas representativo de um ciclo histórico de universalização escolar em Portugal, no final de Oitocentos. Fundamenta-se em documentos do Arquivo Municipal de Ovar e da freguesia de São Vicente de Pereira, como livros de atas, correspondências e imprensa. Recupera-se o processo de construção do prédio da escola para o sexo masculino, entre 1888 e 1892, como resultado do esforço da Junta de Paróquia e de um "brasileiro" daquela freguesia que, para esse fim, conseguiu doação de terreno e significativa quantia de amigos residentes no Brasil. Foi possível perceber parte da complexidade do processo de escolarização que se pretendia em Portugal no final do século XIX.

Palavras-chave: Instrução em Portugal. Construção de escola. Freguesia de São Vicente de Pereira. 


\begin{abstract}
The text focuses on a less enlightened theme in the History of Education in Portugal - the educational statute of the parish in the context of school provision. The parish constituted the geographical, administrative and social instance of school literacy. It is a study of microhistory, perhaps of "small history", but representative of a historical cycle of school universalization in Portugal, at the end of the Eight Hundred. It is based on documents from the Ovar Municipal Archive and the parish of São Vicente de Pereira, such as minute books, correspondence and the press. The process of construction of the school building for boys is recovered between 1888 and 1892, as a result of the effort of the Parish Council and a "Brazilian" of that parish who, for this purpose, managed to obtain donate land and a significant amount of money from friends residing in Brazil. Thus, it was possible to understand part of the complexity of the schooling process that was intended in Portugal in the late nineteenth century.
\end{abstract}

Keywords: Instruction in Portugal. School construction. São Vicente de Pereira parish.

\title{
Resumen
}

El texto se centra en un tema menos investigado en la Historia de la Educación en Portugal - el estatuto educativo de la parroquia en el contexto de la provisión escolar. La parroquia constituyó la instancia geográfica, administrativa y social de la alfabetización escolar. Es un estudio de microhistoria, quizás de "pequeña historia", pero representativo de un ciclo histórico de universalización escolar en Portugal, al final de los Ochocientos. Se basa en documentos del Archivo Municipal de Ovar y la parroquia de São Vicente de Pereira, como libros de actas, correspondencia y la prensa. Fué recuperado el proceso de construcción del edificio escolar para niños varones entre 1888 y 1892, como resultado del esfuerzo del Consejo Parroquial y un "brasileño" de esa parroquia que, con este propósito, logró donacion de tierras y una cantidad significativa de dinero de amigos que residian en Brasil. Así, fue posible comprender parte de la complejidad del proceso de escolarización que se pretendía en Portugal a fines del siglo XIX.

Palabras clave: Instrucción en Portugal. Construcción de escuela. Parroquia de São Vicente de Pereira. 
Este texto surge na sequência de dois estudos anteriores, que versaram sobre os esforços despendidos pela abertura de uma escola feminina na freguesia de São Vicente de Pereira, município de Ovar, na segunda metade do século XIX. O primeiro, partiu de documentação existente na Torre do Tombo e discutiu o tormentoso processo ocorrido entre 1873-1876, de tentativa de doação de uma escola para crianças do sexo feminino, por parte de um industrial da freguesia de São Vicente de Pereira, o "brasileiro" de torna viagem João Rodrigues de Oliveira Santos. A escola destinava-se às filhas de suas operárias de uma fábrica de chapéus. O estudo informa sobre os percalços por que passou junto à Câmara Municipal de Ovar, que negava ou postergava a aceitação do donativo, passando o processo por várias instâncias até chegar à Junta Consultiva de Instrucção Publica, no Ministério do Reino. O conjunto documental então consultado não esclarecia se a escola havia ou não entrado em funcionamento algum dia ${ }^{1}$. $\mathrm{O}$ segundo estudo, elaborado a partir de documentação existente nos arquivos da Junta de Paróquia ${ }^{2}$ da freguesia de São Vicente de Pereira e do Arquivo Municipal de Ovar, retomou a investigação buscando compreender, a partir de novas fontes, as motivações, as dissensões políticas e, finalmente, constatar a inauguração da referida escola para meninas em setembro de 1888, quase 15 anos após o início dos procedimentos burocráticos, que se haviam iniciado em dezembro de $1873^{3}$.

Nessa incursão pelos arquivos de São Vicente de Pereira, foi identificado outro empreendimento nos domínios dessa mesma freguesia, também com a participação do empresário acima citado, que se inicia no mesmo ano de inauguração da escola para meninas, 1888, agora voltado à construção de um prédio para a escola dos meninos, visando a melhoria das condições de trabalho do professor e da aprendizagem dos alunos. Esse segundo movimento, por conta das alterações na estrutura de poder no município de Ovar, não passará pelas dificuldades burocráticas sofridas pela iniciativa anterior, mas não deixará de ser um processo difícil e, às vezes, aflitivo, chegando ao seu final em 1892. Será esse o percurso que tentaremos recuperar nas próximas páginas, na tentativa de clarificar um pouco mais como ocorria o processo de institucionalização do ensino primário em Portugal nos finais do século XIX.

\section{Portugal e os desafios da instrução na segunda metade do século XIX}

A instrução foi considerada como elemento substancial de progresso no território europeu no período de oitocentos, quando a maior parte dos seus países estruturou seus sistemas nacionais de ensino. Consequentemente, foram lançadas as bases para a consolidação das estruturas que passaram a embasar essas sociedades no final desse século e início do seguinte, garantindo ou propiciando o desenvolvimento econômico e o alcance de melhores condições de vida à população: laicismo, democracia representativa, igualitarismo de direitos políticos, liberalismo econômico, acesso universal à educação, etc. No entanto, em Portugal, o andamento dos fatos não seguiu esse traçado, ou, pelo menos, não o fez no mesmo ritmo e nem no mesmo tempo. Ao final do século XIX, Portugal apresentava indicadores econômicos e educacionais muito inferiores à maior parte do restante da Europa, problemas que o marcaram ainda por boa parte do século XX.

\footnotetext{
${ }^{1}$ GONÇALVES NETO, Wenceslau; MAGALHÃES, Justino. Ação privada e poder público na luta pela instrução: Portugal na segunda metade do século XIX. Revista Brasileira de História da Educação, n. 20, 2009, p. 15-39.

2 Ao longo do século XIX a designação dessa instância administrativa é alterada diversas vezes pela legislação, alternando-se como Junta de Paróquia ou Junta de Freguesia. Neste texto, como essas denominações aparecem na documentação nas duas versões, são utilizadas com o mesmo significado.

3 GONÇALVES NETO, Wenceslau; MAGALHÃES, Justino Pereira de. Luta pela instrução e disputas políticas em Portugal na segunda metade do século XIX: a escola para meninas na freguesia de São Vicente de Pereira, Município de Ovar. Sarmiento, v. 23, 2019, p. 51-69.
} 
Analisando as condições sócio-políticas portuguesas e suas interrelações com o desenvolvimento econômico, bem como os indicadores que costumam ser utilizados para a identificação da chamada modernidade, como alfabetização e cultura escrita, entre outros, António Candeias ${ }^{4}$ observa:

Percebemos que democracia, riqueza, alfabetização e direitos políticos, agregados entre si, fazem parte do "progresso" que se encontra associado à ideia de "Modernidade", pelo que durante a segunda metade do século XIX e todo o século XX sociedades com altos índices de alfabetização tendem normalmente a ser apresentadas como ricas, democráticas, com taxas de crescimento demográficas próprias, essencialmente urbanas, como sociedades em que os cidadãos se podem associar livremente e o voto tende a tomar-se universal durante a primeira metade do século XX.

Por essa passagem, percebemos a dimensão do desafio que se colocava para Portugal no período, na busca de seu espaço no concerto das nações europeias. Apesar de se relembrar, como o faz Candeias a seguir, que nem sempre alfabetização plena e desenvolvimento econômico ou político caminham de mãos dadas, no geral, todos os estados que alcançaram patamares significativos de modernidade haviam resolvido antes seus problemas de escolarização. Os indicadores de Portugal, no entanto, mostravam uma situação desconfortável: na virada para o século XX o índice de alfabetismo ainda patinava à volta dos $25 \%$, acrescentando apenas $10 \%$ de alfabetizados em 50 anos, saltando de $15 \%$ em 1850 para 25\% em 1900 (índices aproximados). Enquanto isso, diversos outros países europeus já beiravam a plena alfabetização de suas crianças em idade escolar, ficando na retaguarda, mas com indicadores bem superiores aos de Portugal, Espanha, Itália e Polônia ${ }^{5}$. Desta forma, Portugal se vê distanciar do movimento de escolarização europeu e, também, do ritmo de desenvolvimento do continente, passando a ocupar, segundo Candeias, a "periferia da periferia", situação que se agrava nas primeiras décadas do século XX.

O esforço pela concretização de uma escola nacional frustra-se, portanto, no século XIX. O que não quer dizer que o Estado português tenha simplesmente se omitido ou não tenha enfrentado o problema. Buscando compreender a natureza do processo de nacionalização da educação e a dimensão desse desafio, Justino Magalhães ${ }^{6}$ aponta três importantes aspectos:

Em primeiro lugar, há que reconhecer a importância das dimensões ideológicas, do fomento de estratégias e formas de participação, como reforço do sentido de pertença e de envolvimento cívicos. Em segundo, há que interpretar a prossecução da estatalização da instrução numa dupla orientação: a de que a resolução das questões materiais carecia da abertura e da negociação com os sectores associativo, particular, doméstico, e com o poder local (municipal, paroquial) e, por fim, com a beneficência social; a de que, para assegurar uma determinada uniformidade e uma eficácia da acção no todo nacional, eram necessários princípios orientadores normalizados, uma escrituração e uma governação adequadas, a criação de uma instância de controlo central, agindo de forma integrada, para o que foi criado um sistema de inspecção. Um terceiro aspecto respeita à normalização de conteúdos e métodos, cuja principal intervenção foi a do fomento e da produção de manuais e livros portadores de uma cultura e de uma praxis escolar.

\footnotetext{
${ }^{4}$ Modernidade e cultura escrita nos séculos XIX e XX em Portugal: População, economia, legitimação política e educação. Educação, sociedade \& culturas, n. 31, 2010, p. 149.

${ }^{5}$ Idem, p. 179.

${ }^{6}$ Da cadeira ao banco: escola e modernização (séculos XVIII-XX). Lisboa: EDUCA-Unidade I\&D de Ciências da Educação, 2010, p. 176-177.
} 
Também se observa que Portugal não esteve desatento ao que ocorria no âmbito da educação em outros países europeus. O mesmo Justino Magalhães, em outro texto, destaca: "Prosseguindo a tradição iluminista que visava através da escola formar súbditos de el-rei, no decurso do século XIX, para além de se verificar uma preocupação de aprofundar as capacidades de ler, escrever e contar, pretende-se que a instrução primária vise também uma iniciação ao exercício da cidadania e uma iniciação profissional" ". Havia, portanto, direta contemporaneidade entre o que se debatia no território europeu e o que se proclamava em Portugal. Existe, inclusive, na historiografia, a indicação para uma certa "precocidade" portuguesa nesse campo, com leis que garantiram a obrigatoriedade da presença das crianças na escola, abertura para a educação das meninas, gratuidade do ensino, etc, que remontam ao século XVIII e avançam pelo XIX, configurando a busca por uma escola de massas. Helena Costa Araújo alerta, contudo, que por semelhantes caminhos igualmente passaram outros países periféricos europeus, embora com resultados distintos e que essa condição "deve ser entendida no quadro das relações de poder inter-Estados, como processo comum a todos os países na mesma situação estrutural" 8 . Utilizando-se de caracterização desenvolvida por Yasemin Nuhogiu Soysal e David Strang (1989) ${ }^{9}$, sobre a emergência da escola de massas na Europa no século XIX, com três processos diferenciados, "formas estatais de construção da educação" (atividade centrada no Estado), "formas societais de construção da educação" (intervenção de organizações da sociedade civil) e "construção retórica da educação", busca fazer aproximação com as condições da instrução em Portugal nos oitocentos. Nessa última categoria estariam os "processos de intervenção que se caracterizaram por anunciarem cedo, do ponto de vista temporal, a intenção e interesse estatal na educação pública, em particular no lançamento da escola de massas, mas tardaram na sua realização" 10 . Para a autora, esse último conceito se adequaria para a compreensão do caso português, de criação e debate das condições de formação de um sistema nacional de ensino sem, no entanto, conseguir torná-lo realidade.

António Candeias, trabalhando com os censos demográficos dos séculos XIX e XX, nos traz relevantes considerações sobre as razões do atraso português, que vão muito além da análise dos números e dos percentuais presentes nos quadros estatísticos. Observa que as explicações para o avanço da cultura escrita na civilização ocidental estão associadas, na historiografia, ao movimento dos ciclos econômicos da expansão europeia, com destaque para a revolução industrial; aos desdobramentos oriundos da Reforma protestante e do iluminismo; e à consolidação do conceito de Estado Nação e à criação de sistemas de difusão ideológicos estatais, para "inculcar uma base cultural universal unificadora e geradora de consensos"11, consequentemente, legitimadora da cultura burguesa dominante. Avança, na busca pela justificativa para o atraso português, indicando como as coisas se encaminham diferentemente nos domínios de Portugal, que teve expansão econômica diferente da Europa; não sofreu grande impacto da Reforma protestante, mas sendo muito atingido pela Contra Reforma; a debilidade da industrialização portuguesa; a presença de fronteiras consolidadas e a não existência de "tensões étnicas ou religiosas que necessitassem de aparelhos construtores de uma 'cultura nacional', constituíram-se em factores que parecem ter sempre dispensado a urgência de

\footnotetext{
${ }^{7}$ Um contributo para a história do processo de escolarização da sociedade portuguesa na transição do Antigo Regime. Educação, sociedade \& culturas, n. 5, 1996, p. 18.

${ }^{8}$ Precocidade e "retórica" na construção da escola de massas em Portugal. Educação, sociedade \& culturas, n. 5, 1999, p. 166.

${ }^{9}$ Construction of the first mass education systems in nineteenth-century Europe, Sociology of education, n. 62 , 1989, p. 277-288.

${ }^{10}$ Helena Costa Araújo, op. cit., p. 167.

${ }^{11}$ Ritmos e formas de alfabetização da população portuguesa na transição de século: o que nos mostram os censos populacionais compreendidos entre os anos de 1890 e 1930. Educação, sociedade \& culturas, n. 5, 1996, p. 36-37.
} 
afirmação em termos modernos e sofisticados de uma cultura dominante", ainda que subalterna aos grandes centros de poder europeus ${ }^{12}$.

Também Ernesto Candeias Martins traz considerações interessantes, tanto sobre as dificuldades da implantação da instrução pública no país nos séculos XIX-XX como da presença de "ideias pedagógicas clarividentes que germinaram e que fizeram com que a instrução primária atingisse todas as crianças portuguesas" ${ }^{13}$, embora o processo tenha se completado com grande atraso em relação ao conjunto da Europa. Destaca, para o século XIX, os avanços nas questões referentes à gratuidade e à obrigatoriedade do ensino, ao aumento da rede escolar, à definição dos planos curriculares, dos métodos de ensino, etc. E conclui:

Contudo, é difícil distinguir uma base de princípios comuns em que se alicerçaram todos esses planos, a despeito das ideologias diferentes, e por vezes diferenciadas, dos seus proponentes. $\mathrm{O}$ abismo entre as intenções reformadoras (legislação) e a realidade educativa concreta foi o indicador comum, unido ao flagelo social do analfabetismo e à falta de uma rede escolar mais alargada e sustentada economicamente pelas autarquias (descentralização do ensino) ${ }^{14}$.

Por essas rápidas pinceladas, é possível perceber não apenas as condições precárias em que se debatia a instrução pública em Portugal no quarto final do século XIX, às voltas com problemas nas condições materiais do ensino - número de escolas, condições das casas escolares, material de ensino, etc -, com a formação e com os salários dos professores, com os métodos de ensino, com a escassez de recursos financeiros para a manutenção e praticamente inexistência para a expansão da rede de ensino, com a falta de continuidade nas políticas formuladas pelo Estado, pela contínua ambivalência entre centralização e descentralização, pela persistência sistemática do analfabetismo, etc, etc, mas, e principalmente, a grandiosidade da empreitada para a superação de tamanho desafio. Tarefa monumental, para a qual o Estado não apresentava condições de oferecer alternativa sozinho, cumprindo, como se fez, chamar o concurso das câmaras, da sociedade civil e dos privados, incluindo a benemerência.

Reflexo desse conjunto de problemas, do macro ao micro, podemos visualizar nas condições da instrução na vila de Ovar e na freguesia de São Vicente de Pereira. Ali encontramos escolas quando existem - em péssimo estado de conservação, professores mal pagos, alunos infrequentes, falta de recursos financeiros para o fim da instrução, burocracia que dificulta ou emperra o andamento das iniciativas em prol do ensino, disputas políticas que atrasam ou inviabilizam esses processos, ação privada buscando a melhoria do ensino e o reconhecimento de sua benemérita ação social e diversas outras formas de atuação, como veremos à frente.

\section{Os "brasileiros" e a benemerência em Ovar}

Para avançarmos na compreensão do objeto que nos ocupa, a construção da escola para meninos na freguesia de São Vicente de Pereira, precisamos retomar alguns elementos elucidativos, entre os quais, a origem social do cidadão que apresentará a proposta de doação de terreno e recursos parciais para a edificação da referida escola, bem como auxiliará a Junta de Paróquia nos encaminhamentos burocráticos, aplicação de recursos e contabilidade do empreendimento. Estamos a falar de João Rodrigues de Oliveira Santos (1832-1900), rico "brasileiro" de torna viagem, residente na freguesia, onde havia, em tempos passados,

\footnotetext{
12 Idem, p. 37.

${ }^{13}$ O ideário da Escola Pública Portuguesa entre os séculos XIX e XX. Montagem, v. 10, 2008, p. 16.

${ }^{14}$ Idem, ibidem.
} 
implantado uma moderna fábrica de chapéus (1872-1877), a qual, inclusive, havia motivado a criação da escola para meninas, que foi objeto do primeiro estudo que fizemos sobre a freguesia, já referido. Igualmente, como veremos na sequência, o doador do terreno e outros que contribuíram com a obra, poderiam ser considerados "brasileiros", apesar de não retornados, ainda residentes no Brasil.

A figura do "brasileiro" tem sido estudada por diversos pesquisadores e sua importância dimensionada, principalmente para a região Norte de Portugal ${ }^{15}$. A literatura também se encarregou de registrar sua imagem no século XIX, embora o tenha feito de forma mais estereotipada, apontando traços pouco meritórios de seus modos de ser e agir, embora reconhecendo sua importância econômica e social. Segundo Fernanda Sousa Maia, analisando a trajetória de dois irmãos vareiros e "brasileiros" de torna viagem que, na primeira década do século XX, constroem um moderno prédio para escolas do sexo masculino e feminino na freguesia de Válega, município de Ovar, a literatura destacava "o exotismo da linguagem e do vestuário, a ostentação dos adereços e dos sinais exteriores de riqueza, associados, geralmente, a um perfil psicológico pouco abonatório, em que a imodéstia, a falta de cultura e de educação, decorrentes de um arrivismo endinheirado, são a tónica"16. Sobre a influência constante e variada desses personagens nos assuntos das suas cidades, vilas e freguesias de origem, nas quais promovem melhoramentos diversos, a mesma autora chama a atenção para as motivações que existiam nessas intervenções:

Mera filantropia ou configurando um retorno de jubilação em que era necessário impressionar os demais, chamando a atenção sobre si próprios, através de estridentes acções de benemerência pública que, a nível local, causavam as inerentes consequências simbólicas de poder, elas tinham também uma esperada repercussão mediática ${ }^{17}$.

No caso do município de Ovar, a presença desse personagem, a partir das fontes pesquisadas, parece ter sido marcante. Inclusive, com a mencionada repercussão midiática, por meio da constante aparição nos jornais do município, que anunciam as viagens de chegada e saída dos "brasileiros" que não se fixaram definitivamente no lugar, destacam ações que repercutem na vila, promovidas tanto pelos "brasileiros" presentes como pelos ausentes, representados por algum patrício local. A indicar a importância desse movimento migratório entre Ovar e os destinos além-Atlântico, que incluíam a África e não somente o Brasil, nos jornais do período estudado existem propagandas continuadas sobre os serviços de navegação, que tinham na vila representante para providenciar os devidos bilhetes de viagem. Esses personagens se faziam notar também por outras formas, inclusive, com manifestações públicas relacionadas a importantes fatos políticos ocorridos no Brasil, que são destacadas nos jornais: "resolveram commemorar a abolição da escravatura no imperio que os acolheu e onde, trabalhando esforçada e honradamente, colheram a fortuna que hoje disfructam. O largo da Motta estava no domingo embandeirado e ao centro um coreto destinado á philarmonica" ${ }^{18}$. Em outros momentos, se explicita nas reportagens a imbricação profunda entre a economia local e os recursos advindos dos emigrados, que tanto impulsionam o progresso como podiam trazerlhe problemas em épocas de crise:

15 Cf., por exemplo, ALVES, Jorge Fernandes, O "brasileiro" oitocentista e seu papel social. Revista de História, FLUP, v. 12, 1993, p. 257-296.

${ }^{16}$ A acção dos "brasileiros" de torna-viagem em Ovar: a obra dos irmãos Oliveira Lopes (Válega). Dunas, n. 5, novembro 2005, p. 6.

${ }^{17}$ Idem, p. 7.

${ }^{18}$ MANIFESTAÇÃO. O Povo d'Ovar, 29 de julho de 1888, ano III, n. 105, p. 2. 
Porque tem estado muito subido o cambio do Brazil começa n'este concelho a sentir-se a falta de dinheiro. Muitos dos nossos patricios querem mandar o producto das suas economias, mas a transferencia dos fundos é muito onerosa e por isso todos estão a espera de que o cambio desça. Por este motivo teem paradas muitas obras em casas que se andavam construindo ${ }^{19}$.

Contudo, deve-se observar que a sociedade portuguesa não estava desatenta para com os problemas oriundos da intensa emigração ocorrida no país na segunda metade do século XIX. Tanto a administração central como os governos locais, num país de pequena população, percebiam o perigo ocasionado por essa debandada de mão-de-obra que "podia pôr em causa a sua própria sobrevivência econômica, a representação traumática da emigração acabará por ser um dos traços predominantes no discurso escrito, oficial ou não, presente em Portugal até ao século XX"20. O debate repercute também em Ovar, onde os jornais apresentam, transcrevem notícias ou comentam sobre os riscos e as consequências da emigração ${ }^{21}$, bem como destacam a realidade que afeta a maior parte dos emigrados, e que é muito diferente da glamurosa descrição comumente feita com relação aos "brasileiros" endinheirados, que retornam garbosos e orgulhosos para sua terra. Em reportagem entitulada "Os brazileiros que voltam", encontramos o seguinte quadro:

Sahiram ha dias do Lazareto, de Lisboa, setenta e tantos quarentenarios, a quem o governo tem [de] pagar a despeza da quarentena por serem considerados indigentes. Sabem quem são esses indigentes, d'onde veem? São emigrantes que voltam do Brazil, pobres desilludidos que veem do paiz do ouro, brazileiros que trazem farrapos. E ainda não são elles dos mais infelizes entre os que partiram para o Brazil! Ao menos, puderam voltar, e quando centenas d'elles que não teem dinheiro para a passagem de regresso à pátria, e quantos que andam por là a pedir esmola e quantos que não voltarão nunca! Esperam-se mais indigentes. $\mathrm{Na}$ cidade de $\mathrm{S}$. Paulo numerosos migrantes mendigam pelas ruas! $\mathrm{E}$ continua a lugubre romaria dos illudidos que partem para o Brazil, em busca de fortuna! ${ }^{22}$

Por essas passagens podemos perceber a importância dos "brasileiros" na vila de Ovar e em suas freguesias, bem como entender que não são de se estranhar as diversas marcas deixadas por eles nas localidades, por conta de suas iniciativas. Como já foi dito, se por filantropia ou por busca de reconhecimento social, o certo é que esses enricados, retornados às suas origens ou contribuindo à distância para as melhorias locais, geraram desenvolvimento e propiciaram benfeitorias em grande parte do território português, transmitindo também às populações locais benefícios possibilitados pelas fortunas acumuladas pelos emigrantes que alcançaram sucesso econômico em outras plagas. E em Ovar encontramos várias dessas ocorrências, como a que nos ocupa e que retomaremos à frente.

\footnotetext{
${ }^{19}$ O CAMBIO do Brazil. O Povo d'Ovar, 7 de junho de 1891, ano V, n. 213, p. 1-2.

${ }^{20}$ MAIA, Fernanda Sousa, op. cit., p. 3.

${ }^{21}$ Cf., por exemplo, CONTRA a emigração. O Ovarense, 24 de maio de 1891, ano VIII, n. 409, p. 2.

${ }^{22}$ OS BRAZILEIROS que voltam. O Ovarense, 17 de maio de 1891, ano VIII, n. 408, p. 2-3.
} 


\section{Ovar na segunda metade do século XIX}

Ovar é uma vila localizada na região Centro de Portugal, no Districto de Aveiro. Na segunda metade do século XIX passou por inúmeras transformações que afetaram sua estrutura política, econômica, social e cultural, algumas delas relacionadas aos fatos que vimos tratando, no campo da instrução. Segundo Manuel Bernardo, tratava-se de um "concelho de lavradores e pescadores", onde a "indústria fabril moderna praticamente não existia em Ovar, nos finais do século XIX"23, numa época em que a ruralidade era a característica marcante de Portugal. Principalmente pela proximidade com o mar, as atividades de pesca eram predominantes. Por essa época, o autor menciona como atividades industriais existentes no concelho, apenas a já comentada chapelaria "a vapor" (18721877), de João Rodrigues de Oliveira Santos, na freguesia de São Vicente de Pereira, e um estabelecimento de tecidos e tinturaria de algodões, que teria funcionado nos anos $1890 \mathrm{em}$ Ovar.

As mudanças ocorrem principalmente a partir da década de 1860, marcada pela chegada dos caminhos de ferro em 1865 e todas as possibilidades que se abriam a partir dessa vantagem, em termos de transporte de pessoas, mercadorias, etc e a consequente dinamização das atividades comerciais. No dizer de Rui Martins, o "comboio mudou completamente a vida de Ovar, grande centro urbano e comercial. (...) Por outro lado, desenvolveu o seu comércio, pondo-o em contacto cada vez mais rápido com o Norte e o Sul do País"24.

Ao lado desse importante avanço, a cidade, conforme listagem de melhoramentos apresentada pelo historiador vareiro Alberto Sousa Lamy ${ }^{25}$, se alterou significativamente no período de 21 anos em que Manuel de Oliveira Arala e Costa, político do Partido Regenerador, controlou a Câmara Municipal e administrou o concelho (1866-1887). Fazem parte das mudanças desse período a abertura de diversas estradas, a construção do mercado municipal (1871), a iluminação da vila (1874), a inauguração do teatro (1875), o alargamento da comarca, com a incorporação de três freguesias que pertenciam ao município de Feira (1875-1879), criação da estação de telégrafo-postal (1876), o abastecimento de águas à vila (1877), o surgimento de 2 jornais (1883 e 1886), etc.

Em termos políticos, além do longo período de poder do grupo aralista, há que se destacar as intrigas e disputas que se faziam presentes entre os grupos que se digladiavam - literalmente pelo poder. Os jornais descrevem por diversas vezes a presença dos "caceteiros", personagens muitas vezes determinantes na vitória pela disputa do poder, mormente com o cacete (e armas de fogo) como instrumento de "dissuasão" para que adversários políticos não comparecessem às urnas e garantir-se, assim, o resultado eleitoral desejado. Em Ovar, mas não somente lá, o enfrentamento entre as elites não se dava apenas no plano das ideias, das provocações pela imprensa ou do debate no plenário camarário, mas se explicitava também nas pauladas e nos tiros. Segundo o mesmo Alberto Sousa Lamy, o modelo de política era o caciquismo, e os partidos em disputa (Regenerador e Progressista) eram constituídos pelos "chefes políticos locais, os notáveis, os patrões locais, os influentes eleitorais, os caciques". Para esse autor, o

cacique obtinha o voto do eleitor prometendo-lhe o apoio a suas pretensões: livrar o filho do serviço militar, obter a redução das suas contribuições, conseguir-lhe um pequeno emprego, arranjar-lhe a sua rua, etc. A população agrícola do concelho foi a aliada tradicional dos caciques monárquicos ${ }^{26}$.

\footnotetext{
${ }^{23}$ A indústria no concelho de Ovar. Dunas, n. 2, julho 2002, p. 30.

${ }^{24} \mathrm{O}$ caminho-de-ferro: veio estruturante da evolução sócio-urbana entre Porto e Aveiro, em exemplo Espinho e Ovar. Dunas, n. 6, novembro de 2006, p. 65.

${ }^{25}$ Monografia de Ovar: Freguesias de S. Cristóvão e de S. João de Ovar, 1865-1916. Vol. 2. Ovar: Câmara Municipal de Ovar, 2001.

${ }^{26}$ Op. cit., p. 15.
} 
Em termos culturais e instrucionais também tinha Ovar os seus destaques. Como lembramos acima, no período em foco (1888-1892), estavam em funcionamento o teatro, existiam jornais representativos dos diferentes partidos que disputavam o poder, duas filarmônicas, várias escolas, etc. Além disso, os jornais ofereciam ao público poesias, crônicas, história da formação da vila, anúncios de professores particulares, de livros científicos e de literatura para venda, etc. Ou seja, percebe-se uma certa efervescência cultural no território urbano, que pode ser observada numa reportagem que tanto apela contra o que não se quer que apareça como indica o que se espera valorizar como distintivo da vila:

Commoções politicas, acirradas pelas paixões, tem feito com que se considere o povo de Ovar como um povo quazi no estado selvagem, ignorante, sem a noção do justo ou do injusto; e todavia isto não é verdade, pois que haverá poucas povoações em que a instrucção esteja tão derramada como aqui: basta dizer que, além de cinco escolas officiaes, ha quinze escolas de ensino livre! E o resultado é haver n'esta villa muito poucas mulheres que não saibam ler e escrever. A consequencia immediata sofre-a o correio: todos os dias de 1 hora da tarde ás 6 è preciso um empregado só para venda de $\operatorname{selos}^{27}$.

Uma iniciativa interessante e a indicar contemporaneidade com as preocupações e com as condições sociais da época, relaciona-se à segunda escola pública de Ovar, que fora criada em 1780, e que em 1867, conforme nos relata Joaquim Manoel Monteiro Fidalgo, abre suas portas para o ensino noturno, "pós-laboral, uma experiência quiçá enriquecedora na época, na qual, muito provavelmente o professor [João] Madail não usaria com os alunos a mesma exigência de conteúdos que exigia aos discentes do ensino diurno". Completando-se a informação com a transcrição do edital publicado pelo administrador do concelho, em que se diz: "Faço saber que desde o dia 15 do corrente mês, haverá aula nocturna para adultos e para meninos, que pelas suas ocupações ou de suas famílias não possam frequentar a diurna" 28 . Desta forma, podemos identificar nos responsáveis pela condução dos negócios de Ovar uma certa sensibilidade, tanto para com o ensino de adultos como para com as crianças em idade escolar que, provavelmente por seu envolvimento com as atividades laborais que garantiam o sustento da família, ficavam impossibilitadas de frequentar adequada e continuamente as aulas no período diurno.

Aparecem, ainda, na imprensa, outras discussões interessantes sobre a questão da educação popular, que reforçam a já referida atualidade das elites locais para com o que ocorria na Corte e em outras paragens da Europa. Em texto assinado por João Frederico Teixeira de Pinho $^{29}$, encontramos as seguintes ponderações:

Vê-se, pois que a cifra dos alumnos [do sexo masculino e feminino] não está em harmonia com a população; e muito conviria que os homens sérios verdadeiramente empenhados no progresso da instrucção publica prodigalisassem todas as forças da sua energia social contra a ignorancia o peior flagello da humanidade. Consultai attentamente a historia e lá averiguareis se erramos. Diremos ainda, com um dos maiores vultos da nossa edade: a instrucção deve ser obrigatoria e gratuita; obrigatoria no primeiro grau, gratuita em todos. A instrucção primaria representa os direitos da infancia e da puericia, mais sagrados mesmo que os de pae, porque se confundem com os do Estado.

\footnotetext{
${ }^{27}$ O SERVIÇO telegrapho-postal em Ovar. O Ovarense, 17 de março de 1889, ano VI, n. 298, p. 1.

${ }^{28} \mathrm{O}$ ensino na vila de Ovar. A escola da Arruela. Dunas, n. 18, nov 2018, p. 104.

${ }^{29}$ Memorias e datas para a vila de Ovar. O Ovarense, 10 de novembro de 1889, ano VII, n. 331, p. 1.
} 
O Ovarense, periódico que trouxe a informação acima, iniciado em 1883, era o "Jornal do Partido Progressista", defendendo acirradamente todas as ideias, decisões camarárias, enfrentamentos políticos, práticas de violência, etc que tivessem a ver com o partido. Já $O$ Povo d'Ovar, criado em 1886, representava o Partido Regenerador (papel posteriormente ocupado por A Folha d'Ovar, a partir de 1892). E, igualmente, neste periódico, nos deparamos com discussões que remetem à responsabilidade social da instrução e sobre o seu poder de transformação da sociedade e dos indivíduos. Com a chegada do Partido Regenerador ao poder municipal em 1890, O Povo d'Ovar publica uma série de reportagens em que apresenta uma espécie de "programa", contendo as ações/intervenções consideradas necessárias para o progresso da vila, indicando os problemas e apresentando sugestões para a superação dos mesmos. Referindo-se a uma região costeira do município de Ovar, a Marinha, o articulista chama a atenção para a sua importância, tanto pela densidade de sua população como por ser ela muito obediente, de tal forma que "se o regedor precisa de cabos, recruta-os alli d'um instante para o outro e obriga-os a quaesquer serviços que elles fazem sem lançar uma queixa". Após destacar que a Marinha, precisaria, para seu desenvolvimento, de estrada (para viabilizar a comunicação), de igreja (como parte integrante da educação do povo) e de uma escola, pondera sobre as vantagens desta última: "Instruir o povo, subministrando-lhe ao menos os primeiros elementos é uma tendencia moderna. A instrucção é a base do progresso: é uma semente que produz fructos admiraveis". Mais à frente, arremata:

E o marinhão [habitante da Marinha] que paga para a parochia, que paga para o municipio e que paga para o Estado, nem se approveita da instrucção elementar, nem da secundaria, nem da superior. (...) Será por elle se não queixar que o deixamos ao abandono? É possivel. Ora é para que o marinhão no futuro se saiba queixar, saiba reclamar os melhoramentos de que carece, que nós lhes devemos dar instrucção, creando uma eschola que lhe fique central, aonde possa ir sem grandes dificuldades ${ }^{30}$.

Vemos aí colocado claramente o que se esperava da instrução popular no discurso do século XIX, voltado para o alcance da modernidade, e já observado anteriormente por Justino Magalhães: deixar de formar súditos para formar cidadãos. E, talvez, se possa adiantar que, nessa proposição do jornal, esteja embutida a concepção da instrução como um instrumento direto de conscientização política, capaz de levar o cidadão ao reclamo de seus direitos e a se compreender como parte de um coletivo, tendo-se como horizonte a construção de uma sociedade democrática, daí derivada.

Com relação às condições culturais e instrucionais da freguesia de São Vicente de Pereira, poucas informações aparecem na documentação que antecede ao período de que nos ocupamos. No entanto, é possível recuperar alguns aspectos que auxiliam na compreensão de sua situação particular e de suas relações com o município de Ovar. Além de ter sua comunicação melhorada no período, com a construção de uma estrada ligando-a ao lugar da Agoncida (1890), ocorreu a criação e funcionamento da fábrica de chapéus entre 1872-1877 e a abertura da escola para meninas, por doação de João Rodrigues de Oliveira Santos, em 1888. Esse benemérito, em livro publicado em 1868, quando ainda estava no Brasil, descreve São Vicente de Pereira de forma carinhosa mas reconhecendo sua pequena importância para o quadro geral do município: "Esta aldeia, pela qual o viajante passará - sem duvida - distrahido

\footnotetext{
${ }^{30}$ ADMINISTRAÇÃO municipal V. O Povo d'Ovar, 11 de maio de 1890, ano IV, n. 168, p. 1-2.
} 
ou indifferente, porque nada aqui encontrará que possa particularmente chamar-lhe a attenção, tem - não obstante - para mim encantos indiziveis" ${ }^{31}$. No entanto, segundo Helder J. de Pinho Almeida, deve-se chamar a atenção para a relativa estabilidade populacional da freguesia que, entre 1865 e 1885, apesar das pressões emigratórias do período, consegue manter e até aumentar os seus habitantes, passando de 1081 para 1209 habitantes $^{32}$. Com isso, presume-se que não somente se mantiveram as necessidades de escola para as crianças, como se fizeram aumentar.

Para maior aclaramento das relações entre município e freguesia, em torno dos assuntos da instrução, Justino Magalhães nos alerta para a maior sensibilidade demonstrada pelas paróquias para com os problemas dessa natureza, que afetavam diferentemente essas duas instâncias administrativas. Segundo esse autor,

Era nas Juntas de Freguesia que a sensisibilidade às questões da instrução era mais notória, tendendo os Municípios a regerem-se em consonância com quantitativos demográficos e por conveniência política. Para além de factores de natureza ideológica e de um reforço do elemento urbano face ao rural, o que estava efectivamente em confronto eram distintas expectativas e distintos horizontes pedagógicos. O quadro paroquial era de alfabetização, enquando o quadro municipal era de escolarização e de iniciação à cidadania activa ${ }^{33}$.

Com efeito, a escola era condição e meio para que a freguesia se tornasse local educativo. A escola (as escolas) e não a freguesia eram reconhecidas como local de educação. Diferentemente, o município continha de base e eram-lhe reconhecidas as prerrogativas de soberania e representação pedagógicas. Era local de educação. Talvez por isso, os "brasileiros", retornados ou ausentes, tenham se preocupado tantas vezes em prover suas freguesias do benefício de uma escola primária. Deve-se observar que João Rodrigues de Oliveira Santos menciona em seu livro que a freguesia tinha uma escola régia para meninos e uma particular para as meninas ${ }^{34}$, e daí talvez tenha vindo sua motivação para a doação posterior da escola para o sexo feminino, que seria pública. A escola do sexo masculino também deixava a desejar, sendo múltiplas as reclamações em torno das suas condições de funcionamento, conforme pode ser observado nas atas da Junta de Paróquia de São Vicente de Pereira. Em 30 de abril de 1882, por exemplo, foi apresentada uma reclamação do professor da escola expondo a "incapacidade da caza para o ensino elementar, em vista do grande numero de alumnos que a querem frequentar" 35. A Junta reconhece a justeza da reivindicação, mas afirma não poder resolver a questão, já que na "parochia não ha edificio privativo e especial para a eschola nem predios particulares que se possão alugar para tal fim". Alguns anos depois, em 13 de fevereiro de 1887, surge nova reclamação do professor, "acerca d'uma mobilia que no anno de mil e oitocentos e oitenta e quatro fora mandada comprar pela Junta de Parochia que então geria os negocios da freguezia, para servir na sua eschola, cuja mobilia nunca lhe foi entregue n'em se sabe onde existe".

\footnotetext{
${ }^{31}$ SANTOS, João Rodrigues de Oliveira. Horas Vagas: poesias e prosa. Maranhão [São Luís]: Typ. do Frias, 1868, p. 115.

${ }^{32}$ A complexidade nos agregados domésticos da freguesia de S. Vicente de Pereira, na $2^{\text {a }}$ metade do século XIX. Dunas, n. 14, novembro de 2014, p. 26-28.

${ }^{33}$ Da cadeira ao banco, op. cit., p. 235-236.

${ }^{34}$ SANTOS, João Rodrigues de Oliveira, op. cit., p. 114.

35 JUNTA de Parochia de S. Vicente de Pereira. Livro de Actas, de 30 de setembro de 1879 a 26 de junho de 1887 [8 de outubro de 1893]. Arquivo da Junta de São Vicente de Pereira. Embora o termo de abertura do livro mencione seu final em 26 de junho de 1887, os registros das atas no mesmo avançam até 8 de outubro de 1893. As menções seguintes à Junta de Paróquia de São Vicente de Pereira provêm todas desta mesma fonte documental.
} 
Vemos, por essas menções no livro de atas da Junta de Paróquia, que São Vicente de Pereira realmente necessitava de uma casa construída especificamente para a escola, visto não haver na localidade edificação disponível e apropriada para esse fim. Da mesma forma, temos presente indicações de como questões burocráticas travavam as iniciativas tomadas na busca de melhorias, como o atraso na entrega da mobília escolar, com demora de 3 anos ou mais. A justificativa, portanto, para a doação do terreno e de recursos para o auxílio da construção de um prédio escolar moderno para a freguesia estava patente. E os "brasileiros" de São Vicente de Pereira perceberam aí uma forma não apenas meritória, em busca de reconhecimento social, mas uma oportunidade concreta, para contribuírem para o adiantamento das condições instrucionais da freguesia e, consequentemente, melhoria do futuro das crianças do lugar.

\section{A escola para meninos em São Vicente de Pereira}

Feita essa contextualização, envolvendo Portugal e Ovar na segunda metade do século XIX, bem como sobre as condições gerais da instrução no país e no concelho, avançando para a freguesia de São Vicente de Pereira, cremos poder apresentar agora a documentação pertinente à formulação da ideia, o caminhar do processo e à construção da escola para o sexo masculino, destacando seus principais momentos e os percalços por que passou entre 1888 e 1892.

A situação política em Ovar melhorou para os progressistas após a vitória nas eleições camarárias de 1886, passando esse grupo, ao qual era ligado João Rodrigues de Oliveira Santos, a controlar o Concelho a partir de 1887. Nesse novo cenário, como já foi lembrado, foi possível proceder-se à aceitação da doação desse personagem para a escolas das meninas, concretizada em 1888 e, nesse mesmo ano, avançar para a resolução dos graves problemas que afetavam o prédio escolar da escola primária masculina. A primeira discussão, constante nas atas da Junta de Paróquia, ocorreu no dia 24 de janeiro de 1888 e, apesar do presidente destacar as limitações do prédio em uso pela escola, a necessidade de solicitação de subsídio ao governo e de uso de donativos de portugueses ausentes para a edificação de nova escola, não se faz menção aos nomes dos doadores, indicando apenas a disposição dos mesmos para tal fim:

visto esta Junta ter de pagar aluguer d'uma caza para a eschola do sexo masculino d'esta freguezia, e não haver caza para alugar nas devidas condicções para exercício de tal mister, e a caza em que a eschola está presentemente postada ser muito incompetente, já por falta de luz e mesmo porque não tem as condicções hygienicas necessarias, porque sendo um tanto subterranea é muito fria e indecente, e n'este cazo tendo em consideração os motivos com que a instrucção infantil é altamente prejudicada e desprezada, e tendo em vista varias ofertas de donativos de cavalheiros conterraneos, auzentes, propunha que se representasse a S. M. Elrei implorando um subsidio para com este e com os donativos supra se edificar uma caza que contenha as condicções necessarias para evitar os efeitos com que a instrucção publica está sendo damnificada. Esta proposta foi unanimemente approvada por todos os vogaes. Em seguida foi por ele Presidente apresentado o progecto para a alludida caza com o respectivo orçamento supplementar, os quaes a Junta acordou unanimemente aprovar, constando o referido orçamento da despeza orçada de 620:000 reis e de receita egual, sendo as proveniencias, de donativos 310:000 reis e egual quantia de subsidio do Governo. 
Estava dado o passo inicial, mas muito havia ainda por se fazer. Em primeiro lugar, era necessário enfrentar o problema da demora por que passavam as providências burocráticas relacionadas à solicitação do subsídio governamental, que precisavam ir da Junta para a Câmara de Ovar e, após aprovação desta, para o Governo Civil de Aveiro e, finalmente, para a administração central em Lisboa. Com percurso igual à volta. Mesmo que não houvesse qualquer contestação ou sobressalto, o período de tramitação de um processo não era curto. Daí a importância de iniciá-lo com a maior brevidade, inclusive, para se aproveitar a atuação do deputado do Partido Progressista, que ora representava o concelho junto ao Governo. Como veremos à frente, o orçamento e o projeto da escola serão substancialmente alterados no decorrer dos acontecimentos e novas alternativas de financiamento terão de ser pensadas pela Junta de Paróquia. Em 27 de maio de 1888 a proposta de doação foi formalizada junto à administração da freguesia:

foi prezente uma carta do Exmo. Snr. João Rodrigues d'Oliveira Santos, do logar da Torre, na qual mostra que havendo tomado em consideração o desprezo à instrucção publica d'esta freguesia (...); e outrossim pedira ao Snr. Dr. Barboza de Magalhães dignissimo deputado por Ovar para que se interessasse por que se obtivesse do Governo o subsidio que esta Junta resolveu solicitar em sessão de 24 de janeiro ultimo, e que solicitara e obtivera dos nossos conterraneos rezidentes no Brazil, os snrs. - Manoel Alves da Cruz e Antonio Gomes Leite os donativos - do primeiro $100 \$ 000$ reis fortes e do segundo além de egual quantia uma propriedade de terra lavradia cita no referido logar da Torre, faceando com a estrada publica do lado leste, para nesta se edificar a escola para a instrucção do sexo masculino, passando a ser arrendada a quem mais der o terreno que ficar desocupado a fim de com o respectivo rendimento se ir formando uma pequenina biblioteca adequada á instrucção publica dos habitantes d'esta freguezia e que se prontificava a passal-as por escriptura de doação a esta Junta, tanto a sua valiosissima oferta, como também a propriedade rectro do benemerito Antonio Gomes Leite, visto achar-se competentemente habilitado com procuração especial d'este para esse fim, quando esta Junta designasse.

A Junta de Paróquia aprova imediata e unanimemente a doação, registra voto de louvor em favor de João Rodrigues de Oliveira Santos e marca reunião no próximo mês, para o registro oficial da proposta e dar sequência nos encaminhamentos. Em 29 de junho, em sessão extraordinária, as questões formais foram resolvidas. Inicialmente, o presidente observou ser essa "sessão excluzivamente destinada a commemorar um facto da maior importancia para esta freguezia, sob o ponto de vista da instrucção primaria", mandando a seguir que fosse transcrita a carta acima aludida de João Rodrigues de Oliveira Santos. Os principais pontos da carta referiam-se à questão do subsídio governamental, que deveria ser alcançado por "intermedio do muito zeloso e digno deputado por este circulo, o Exmo. Snr. Dr. Barboza de Magalhães, que, muito cavalheirosamente, me prometeu para esse fim o seu valioso patrocínio"; os nomes dos doadores, residentes no Brasil; a descrição da "propriedade de terra lavradia" e dos valores prometidos; e a observação complementar sobre o uso do terreno que sobrar após a construção da escola, que deveria ser arrendado e, com o produto, "se formar uma pequenina biblioteca de livros adquados á instrucção popular". A seguir, o presidente da Junta informou que já providenciara em Ovar o registro da doação do terreno oferecido e que vira igualmente a escritura do mesmo, a qual estava sem qualquer pendência. Foi, ainda, registrado novo voto de louvor, agora aos doadores do terreno e dos recursos financeiros e definido que se pedisse à imprensa a publicação da ata da Junta, por "ser esse não só o melhor meio de mais amplamente se manifestar aos benemeritos doadores a inolvidavel gratidão d'este povo, mas tambem o mais adquado para auxiliar o contagio benéfico dos nobilissimos sentimentos de que aquelles cavalheiros se inspiraram". 
Destacaríamos nestes excertos a menção à necessária intervenção do deputado representante do município para o alcance do subsídio, denotando as relações de dependência das pequenas localidades com as elites políticas; a repercussão midiática da doação dos "brasileiros", ao se indicar a publicação de cópia da ata da Junta; o estímulo a novas doações por parte de "brasileiros", buscando-se o "o contagio benéfico dos nobilíssimos sentimentos"; e a referência à formação de uma biblioteca popular. Segundo Ernesto Candeias Martins, falando das bibliotecas populares, teria sido essa uma importante iniciativa da educação portuguesa no século XIX, instituída pelo Decreto-Lei de 2 de agosto de 1870: "pretendiam levar a população a aprender a ler, incluindo a leitura nos domicílios (art. $5^{\circ}$ ) correspondendo às intenções educativas que seguiam outros países europeus (Suíça, Prússia, França, Espanha, Inglaterra, Alemanha e Suécia)" ${ }^{\text {36. }}$.

No jornal $O$ Ovarense encontramos os ecos dessas iniciativas, em reportagens que anunciam as doações ocorridas em São Vicente de Pereira para a construção da escola do sexo masculino. Em uma, o articulista fala da decisão da Junta de Paróquia, tece elogios aos benfeitores da freguesia, louva o zelo do deputado pelo concelho e finaliza: "Acções d'estas glorificam-se com todo o enthusiasmo e registam-se indelevelmente. Bem hajam os insignes benemeritos!"37. Em outra, traz a transcrição da ata de 29 de junho de 1888, da Junta de Paróquia, tornando realidade o que fora definido ao final dessa sessão extraordinária da Junta ${ }^{38}$. Da mesma forma, a Câmara de Ovar acompanhou o desenrolar do processo e dava ao mesmo a necessária aprovação para a sua continuidade. Em sessão no dia 23 de maio de 1888, a Câmara

approvou o orçamento supplementar da junta de Parochia de S. Vicente para a construcção d uma caza para escola do sexo masculino, mandando lançarlhe o accordão do theor seguinte:- Visto o presente orçamento supplementar da junta de Parochia de S. Vicente: Considerando que é de necessidade e de utilidade a construção d'uma casa para eschola do sexo masculino da referida freguezia; considerando que estão convenientemente equilibradas a receita $\mathrm{e}$ a despesa; E considerando que se cumpriram as formalidades respectivas; A Camara Municipal d'Ovar, em sessão de 26 de maio de 1888, accorda em approval-o, recommendando á junta da Parochia de S. Vicente a exacta observancia do $\operatorname{art}^{\circ} 390$ do Codigo Administrativo ${ }^{39}$.

Em sessão de 30 de setembro de 1888, a Junta de Paróquia, discutindo a "péssima disposição em que estava sendo ministrada a instrucção primaria" e a demora para aprovação do subsídio para a construção da escola, propõe que se buscasse acelerar o processo e que a "Junta se obrigasse diretamente a construir a referida caza dentro do espaço d'um anno contado da data em que se obtiver o aludido subsidio". Aprovado esse encaminhamento, o presidente apresentou novo projeto e orçamento para o prédio, em que se previa "despeza de um conto e trezentos e cincoenta mil reis e de egual receita, sendo as proveniencias - de donativos seis centos e cincoenta mil reis e de egual quantia de subsidio do governo". Esse orçamento foi aprovado na Câmara de Ovar na sessão de 12 de dezembro de 1888. O novo valor previsto para a construção da escola, dobrando o custo original, deve ter sido juntado ao processo que solicitava o subsídio, pois, como veremos à frente, será com base nele que será aprovado o auxílio por parte do Governo.

\footnotetext{
${ }^{36}$ Op. cit., p. 26.

${ }^{37}$ BENEMERITOS. O Ovarense, 10 de junho de 1888, ano V, n. 258, p. 2.

${ }^{38}$ BENEMERENCIA em favor da instrucção popular. O Ovarense, 8 de julho de 1888 , ano V, n. 262, p. 1-2.

${ }^{39}$ CÂMARA Municipal de Ovar. Livro de Actas n. 32, de 12 de Fevereiro de 1887 a 14 de Junho de 1890. Arquivo Municipal de Ovar. As menções seguintes à Câmara Municipal de Ovar provêm desta mesma fonte documental.
} 
Na sessão de 3 de março de 1889, o presidente informa à Junta de Paróquia a aprovação do orçamento suplementar pela Câmara de Ovar e que foi autorizada também a "alienação d'alguns terrenos baldios d'esta parochia", visando fazer frente às despesas, entre as quais, os valores complementares aos donativos recebidos e ao subsídio previsto do Governo, necessários para a construção do prédio da escola, resolvendo-se, portanto, colocar em arrematação os referidos imóveis. Constam, no livro de atas da Junta, dois autos de arrematação: um, do dia 14 de abril de 1889 , em que foi vendido apenas um dos terrenos baldios, por $70 \$ 272$ réis; e outro, de 9 de junho de 1889, em que consta a venda de três terrenos baldios: o primeiro foi dividido em duas partes, rendendo, respectivamente, $20 \$ 350$ réis e $3 \$ 160$ réis; o segundo terreno foi vendido por $6 \$ 003$ réis; o terceiro também foi dividido, rendendo cada parte $47 \$ 520$ réis. No total, foram arrecadados para os cofres da Junta de Paróquia, 194\$825 réis, que seriam suficientes para cobrir os gastos com a construção da escola, quando somados aos recursos que haviam sido dados em doação e ao subsídio a ser concedido pelo Governo.

Quando da primeira arrematação já se conhecia o resultado do pedido de subsídio, pois, na sessão de 7 de abril de 1889, foi anunciada sua aprovação pelo Ministério do Reino, pela portaria de 16 de fevereiro desse ano, no valor de 650\$000 réis, divididos em duas parcelas iguais, uma ao meio e outra ao final da construção da escola. Foi, inclusive, registrado um voto de louvor ao deputado que representava o concelho, Jose Maria Barboza de Magalhães, "pelos relevantes serviços, modo incançavel e protecção incorrespondivel, que tão valorosamente se dignou dispensar-nos". Estava vencida a primeira fase da luta pela construção da escola, respeitante à aprovação do subsídio governamental, recebimento de donativos e do terreno e à arrecadação de receitas complementares para sustentar o empreendimento. Podia-se, agora, passar a uma nova fase, da construção propriamente dita.

O passo seguinte buscou garantir celeridade ao processo, pois a portaria que concedia o subsídio governamental estabelecia que a obra deveria ser completada no limite de um ano após o recebimento da primeira parcela do subsídio. Para isso, solicitou-se, ao Governador Civil, em 26 de maio de 1889, que remetesse à Junta, com a maior brevidade possível, as sugestões porventura apresentadas pelo "Director das obras publicas do Districto", de alteração na planta da escola, documento indispensável para se fazer o edital de arrematação da obra. Em 30 de junho desse mesmo ano, o presidente da Junta diz que, estando de posse de toda a documentação necessária e "atendendo a que se torna curtissimo o espaço concedido para a construcção da caza d'eschola d'instrucção primaria do sexo masculino, (...) propunha que, sem mais perda de tempo se abrisse concurso para a referida construção". Foram aprovadas as condições para o edital, incluindo planta, orçamento, exigências e prazos:

primeira, admitindo para base da licitação a quantia de 1:020\$000 reis; segunda, que o pagamento será feito em duas prestações eguaes, uma quando a construção estiver a meio, e a outra, quando esteja concluída; terceira, que o adjudicatório dará fiador edoneo ao fiel cumprimento do contracto, ao qual a Junta garantirá o preço da construcção; quarta, que o concorrente apresentará sua proposta por carta fechada endereçada a Junta de Parochia; quinta, que a Junta reserva o direito de abrir novo concurso se entender conveniente aos interesses d'esta Parochia, no edifício escholar do sexo femenino, d'esta freguezia, por espaço de 20 dias, a contar d'esta data, afim dos interessados poderem ver, examinar, calcular e entregar á illustrada Professora suas cartas de propostas, na forma designada; e que serão abertas em sessão d'esta Junta de 21 de Julho, proximo futuro. 
O edital foi publicado pelo $O$ Ovarense, em que se destacava: “A planta, orçamento e mais condições relativas a este concurso, acham-se patentes todos os domingos, dias santos e quintas feiras, das 9 às 12 horas da manhã, no edificio da escola primaria do sexo feminino, Torre, d'esta freguezia"40. A despeito da divulgação por editais e pela imprensa, a arrematação não ocorreu, por falta de propostas, no dia 21 julho de 1889 , sendo decidida na reunião da Junta, ocorrida nessa data, a prorrogação do prazo até o dia 28 do mesmo mês. Enfim, nesta nova data, foram apresentadas 6 propostas, variando de 1:300\$000 a 994\$000, sendo esta última considerada vencedora. A Junta de paróquia oferece como garantia para a construção o subsídio governamental, "a propriedade em que vae ser edificada a caza d'eschola, e os donativos, em dinheiro, ainda existentes em poder do Exmo. Snr. João Rodrigues d'Oliveira Santos". Para gerar mais alguma receita que pudesse auxiliar na manutenção das obras da escola, a Junta de Paróquia, em 8 de junho de 1890, após discussões em sessões anteriores, decide arrendar para plantio a parte do terreno não utilizada pelo prédio da escola pela quantia de $1 \$ 800$ réis. Com esses encaminhamentos, mais um passo estava dado rumo à concretização do prédio da escola.

Entrementes, surgem problemas. Primeiro, em 6 de julho de 1890, o arrematante solicita dilação por mais 6 meses no prazo de entrega da obra, por "lhe terem faltado no trato as canteiras com quem ajustara a esquadria, portaes e janelas", impossibilitando concluir o prédio no prazo estipulado. A nova data de finalização passaria a ser 20 de janeiro de 1891 e a "Junta atentando no assumpto e reconhecida do facto alegado, deliberou conceder-lhe a prorrogação". Segundo, registra-se na ata da Câmara de Ovar, na sessão de 11 de outubro de 1890, um acórdão do Tribunal Administrativo de Aveiro, "revogando as deliberações da Junta de Parochia da freguezia de S. Vicente de Pereira ácerca da venda d'uns terrenos baldios pertencentes á mesma junta que esta vendeu sem previa auctorização do Governo e da Junta Districtal"41. O fantasma da falta de recursos para a conclusão da obra voltará a rondar a Junta de Paróquia da freguesia de São Vicente de Pereira.

O primeiro desafio para a quitação da obra foi colocado na sessão de 12 de outubro de 1890, quando o arrematante solicitou a primeira parte do pagamento "que, ponderou julgar demasiadamente vencido, porquanto que tinha respectiva construcção precizamente prompta nas trez quartas partes". Como a Junta, para fazer jus ao recebimento da primeira parte do subsídio, fundamental para poder quitar o primeiro compromisso, precisava demonstrar ao Governo que já estaria a meio o andamento da construção, deliberou-se pelo envio de ofício ao Diretor das obras Públicas do Distrito de Aveiro, para que fosse enviado fiscal que fizesse a vistoria da obras. Na sessão seguinte, em 27 de outubro do mesmo ano, compareceu à Junta o engenheiro enviado por Aveiro, declarando:

que a obra de pedreiro do edifício da eschola estava completa, com excessão das escadas exteriores; a obra de trolha tem os trabalhos completos, e em começo os guarnecimentos exteriores; e a obra de carpinteiro em via de conclusão, restando apenas as portas interiores e os guarnecimentos na habitação do professor. Disse ainda o Snr. Engenheiro que as obras tem sido feitas com segurança, e que hão sido cumpridos os progectos aprovados pela Direção das Obras Publicas d'este Districto d'Aveiro.

\footnotetext{
${ }^{40}$ CONCURSO. O Ovarense, 7 de julho de 1889, ano VI, n. 313, p. 3.

${ }^{41}$ CÂMARA Municipal de Ovar. Livro de Actas n. 33, de 21 de Julho de 1890 a 17 de Julho de 1893. Arquivo Municipal de Ovar. As menções seguintes à Câmara Municipal de Ovar provêm todas desta mesma fonte documental.
} 
Com este laudo, habilitava-se a Junta de Paróquia a receber metade do subsídio governamental, no valor de $325 \$ 000$, minorando momentaneamente as pressões sobre os cofres da freguesia. No entanto, o alívio dura pouco: na sessão extraordinária, de $1^{\circ}$ de novembro de 1890, chega à freguesia o acórdão do Tribunal Administrativo de Aveiro, que passara anteriormente pela Câmara de Ovar, pelo qual "a Junta foi claramente conhecedora de lhe haverem sido anuladas as deliberações constantes da sessão de 22 de julho de 1888 , relativas á alienação dos terrenos baldios". Percebida a gravidade e a irreversibilidade da situação, propõe o presidente que "expozesse desde já á disposição dos compradores as quantias d'elles recebidas, e em cofre"; e que, dada a continuidade da carência de recursos, por "inesperadamente faltaram alguns donativos com que se contava para complemento das verbas, para a edificação da caza d'eschola d'instrucção primaria do sexo masculino", com a construção já em andamento, "se propusesse, por modo legal, a venda dos referidos terrenos baldios", para o que seriam solicitadas instruções às instâncias superiores. Apesar de o presidente da Junta referir-se, sem mencionar nomes, a possíveis donativos que não se tornaram realidade, deve-se observar que outras formas de colaboração também se fizeram presentes, expondo o caráter coletivo que toma a construção do edifício escolar. Em 10 de novembro de 1889 foi anotado nas atas da Junta de Paróquia que João Rodrigues de Oliveira Santos havia informado que a "planta e orçamento respectivo [da casa da escola] fora preparada pelo Snr. Thomaz Antonio Ferreira, da Venda-nova, do Couto de Cucujães, e lhe fora entregue sem indemnização de trabalho, e com a declaração de que o fazia em beneficio da instrucção publica". A Junta, imediatamente, registra um voto de louvor, em "signal de agradecimento pelo donativo com que se dignou concorrer, auxiliando e prezenteando assim, com o fructo de seu trabalho a todos os habitantes d'esta freguesia".

A obra atrasava, mas não apenas por conta dos problemas financeiros enfrentados pela Junta de Paróquia. Novamente, na sessão de 18 de janeiro de 1891, o arrematante da construção demanda adiamento na entrega, alegando falta de espaço no terreno "annexo á mesma caza para o necessário deposito de materiaes respectivos, porquanto, que o terreno disponivel para isso havia sido ocupado pelos materiaes pertencentes á obra de trolha”. Como o arrematante ainda não havia recebido a primeira parte do seu pagamento, podemos presumir que, na realidade, procurava postergar a finalização da obra, como meio de pressionar a freguesia a lhe pagar o que era devido. A Junta aquiesce à solicitação e o novo prazo fixado para 30 de junho do mesmo ano. A Câmara de Ovar aprova essa mesma prorrogação na sessão de 3 de fevereiro de 1891.

Em 12 de abril de 1891, finalmente, a Junta acusa o recebimento do primeiro pagamento do subsídio governamental, no valor de $325 \$ 000$ e que, por ainda estar em falta com o pagamento do arrematante, o presidente "propunha se saptisfizesse sem perda de tempo, para que o aludido arrematante podesse abreviar a conclusão dos trabalhos". Para completar os 497\$000 réis devidos, utilizou-se parte dos donativos que se encontravam sob a guarda de João Rodrigues de Oliveira Santos. Mais um momento de alívio para a Junta.

Em 24 de maio de 1891, o presidente da Junta argumenta junto aos vogais sobre a pertinência de se proceder à venda do terreno sobrante às necessidades do prédio da escola, residência do professor e pátio esportivo, cujo valor, estimado em mais de $100 \$ 000$ réis, poderia render, em títulos do governo, muito mais do que os $2 \$ 000$ réis auferidos naquele momento com o arrendamento do terreno. Como o doador do terreno já havia sido contatado no Brasil e concordado com a transação, a proposta foi aprovada. Comunicada da decisão, a Câmara de Ovar, em sessão de 8 de junho de 1891, deliberou "auctorizar a referida junta para aquella venda, na parte que lhe diz respeito". Colocado em edital de arrematação, no dia 25 de outubro de 1891, o terreno foi vendido por $151 \$ 500$ réis e o produto, por intermédio de João Rodrigues de Oliveira Santos, transformado "em inscripções do Governo Portuguez averbadas a mesma Junta, com a obrigação d'esta empregar anualmente os juros das referidas inscripções em livros adquados a formação, na mencionada eschola de uma biblioteca para instrucção popular". 
Ainda que com mais algum atraso, a obra chega ao fim. Na sessão de 13 de setembro de 1891 o arrematante requereu da Junta o restante do pagamento, justificando "haver dado conclusão aos trabalhos, saptisfeito o seu compromisso nos termos e clausulas da arrematação". A Junta recomeça, então, os procedimentos junto ao Diretor de Obras Públicas do Distrito de Aveiro, solicitando nova vistoria. O competente laudo foi registrado na sessão de 5 de outubro de 1891, com o engenheiro declarando "que a obra estava completa, d'harmonia com a planta e orçamento aprovados" e, por conseguinte, ficando apta a Junta a requerer a segunda parcela do subsídio a que tinha direito. Em vista do parecer do engenheiro sobre o edifício da escola, a Junta "igualmente julga a edificação da mesma em disposição aceitavel e por isso a aprovou". Com isso, poder-se-ia dar andamento ao processo, junto às instâncias superiores, para a liberação dos valores restantes do subsídio governamental.

Na sessão de 22 de novembro de 1891, o presidente informa aos presentes que João Rodrigues de Oliveira Santos havia conseguido, já há algum tempo, de Antonio Domingues Geraldo e sua esposa, conterrâneos residentes no Brasil, mais uma doação para a escola do sexo masculino, no valor de $18 \$ 000$ réis, "empregada em mobilia para a mesma eschola". Foi registrado um ato de gratidão da Junta para com os benfeitores. No mês seguinte, na sessão de 20 de dezembro de 1891, o mesmo João Rodrigues de Oliveira Santos, depositário dos donativos conseguidos para a escola, apresentou à Junta uma prestação de contas das movimentações financeiras de que fora responsável. O quadro final ficou assim transcrito na ata:

\begin{tabular}{|c|c|c|c|c|}
\hline & & & Deve & Haver \\
\hline 1888 & & $\begin{array}{l}\text { Donativo que obtive do Snr. Antonio Gomes Leite, da } \\
\text { Bahia para a escola do sexo masculino }\end{array}$ & & 100:000 \\
\hline “ & & $\begin{array}{l}\text { Dito do Snr. Manoel Alves da Cruz, do Pará para o } \\
\text { mesmo fim }\end{array}$ & & 100:000 \\
\hline 1889 & & $\begin{array}{l}\text { Dito do Snr. Antonio Domingues Geraldo, do Ceará, } \\
\text { idem }\end{array}$ & & 18:000 \\
\hline “" & & $\begin{array}{l}\text { Dinheiro que entreguei ao Snr. Prezidente da Junta, } \\
\text { Antonio Jose da Silva para pagamento ao Vinhas } \\
\text { [arrematante da obra] }\end{array}$ & 117:000 & \\
\hline 1891 & & $\begin{array}{l}\text { Dito que o mesmo Snr. Silva me entregou para compra } \\
\text { de inscripções }\end{array}$ & & $50: 000$ \\
\hline \multirow[t]{2}{*}{ Novembro } & 27 & $\begin{array}{l}\text { Compra de trez inscripções que remeti a Junta pelo } \\
\text { correio }\end{array}$ & $133: 835$ & \\
\hline & & Porte da carta registada & 175 & \\
\hline \multirow[t]{2}{*}{ Dezembro } & 9 & $\begin{array}{l}\text { Compra da obrigação } \mathrm{n}^{\circ} 090550 \text { de emprestimo para as } \\
\text { estradas, que fica em meu poder a disposição da Junta }\end{array}$ & 17:000 & \\
\hline & & Diferença a meu favor, para fechar & $268 \$ 010$ & $268 \$ 000$ \\
\hline
\end{tabular}

Como o leitor já deve ter notado, mesmo com o subsídio governamental e as doações dos beneméritos, a relação entre a receita e a despesa da construção do prédio da escola não se equivaleria, por conta da anulação da venda dos terrenos baldios. Essa situação será reconhecida pelo presidente da Junta de Paróquia na sessão de 17 de janeiro de 1892, demonstrando a incapacidade da freguesia em quitar o débito referente à construção da escola e propondo a abertura de um empréstimo para lhe fazer face: 
pagamento para que se incluiu em orçamento apenas a verba de $850 \$ 000$ reis quando a importância total é de $994 \$ 000$ reis por que o dito arrematante espera se lhe saptisfaça; porquanto como desde a promoção do orçamento ordinário não tenhão surgido meios suficientes para facear a restante quantia de $144 \$ 000$ reis nem tampouco a preveja havel'os de futuro, propunha se contraísse um imprestimo oneroso da citada quantia em falta de cento e quarenta e quatro mil reis subgeitando esta Junta aos juros respectivos ate que haja recursos, e possa ser amortizada.

Por depender a formalização de tal empréstimo de aprovação superior, provavelmente não foi conseguida, pelo menos nos meses seguintes. Na sessão extraordinária, de 31 de dezembro de 1892, finalizando as atividades anuais, a Junta declara que deve ao arrematante da escola do sexo masculino "a quantia de cento e quarenta e quatro mil reis, como resto da quantia de nove centos e noventa e quatro mil reis, (...) visto que apenas lhe saptisfez a quantia de oito centos e cincoenta mil reis, por orçamento do corrente anno". O livro de atas da Junta de Paróquia da Freguesia de São Vicente de Pereira encerra-se em 8 de outubro de 1893, sem mencionar o desfecho da dívida. Informações complementares também não foram encontradas nas atas da Câmara Municipal ou nos jornais de Ovar.

Com relação à escola, podemos concluir que entrou em funcionamento no novo prédio em 1892, uma vez que, na sessão de 14 de fevereiro desse ano, o presidente

fez sciente a todos os vogaes, que na ultima quarta feira 10 do corrente tivera, na sua presença, a nova caza d'eschola primaria do sexo masculino, d'esta freguezia, vistoria e exame sanitário pelo Snr. SubInspector Escolar; e que o mesmo empregado concluira por dizer que a caza referida estava nas devidas condições para o exercicio da referida eschola; e por isso auctorizava a entrada do respectivo professor ali e para exercer taes funções, na próxima segunda feira 15 do corrente. Em virtude do que dera publicidade a edital prevenindo a mencionada mudança d'eschola. Em seguida atentando a Junta no mesmo assumpto resolveu mais fazer a competente communicação ao respectivo professor para o mesmo fim.

Pelas ilustrações inseridas abaixo é possível perceber a solidez da construção da escola que entrou em funcionamento no ano de 1892, ainda atualmente em bom estado de conservação, bem como os elementos modernos do seu traçado, além de aparentar condições adequadas de aprendizagem e de conforto para o professor e os meninos da freguesia. Ao final, a Junta de Paróquia e a filantropia dos "brasileiros" legaram uma obra que persiste no cenário educacional da freguesia, ainda que não mais funcione como unidade educativa. 
Figura 1: Escola primária para o sexo masculino, em São Vicente de Pereira (2014)

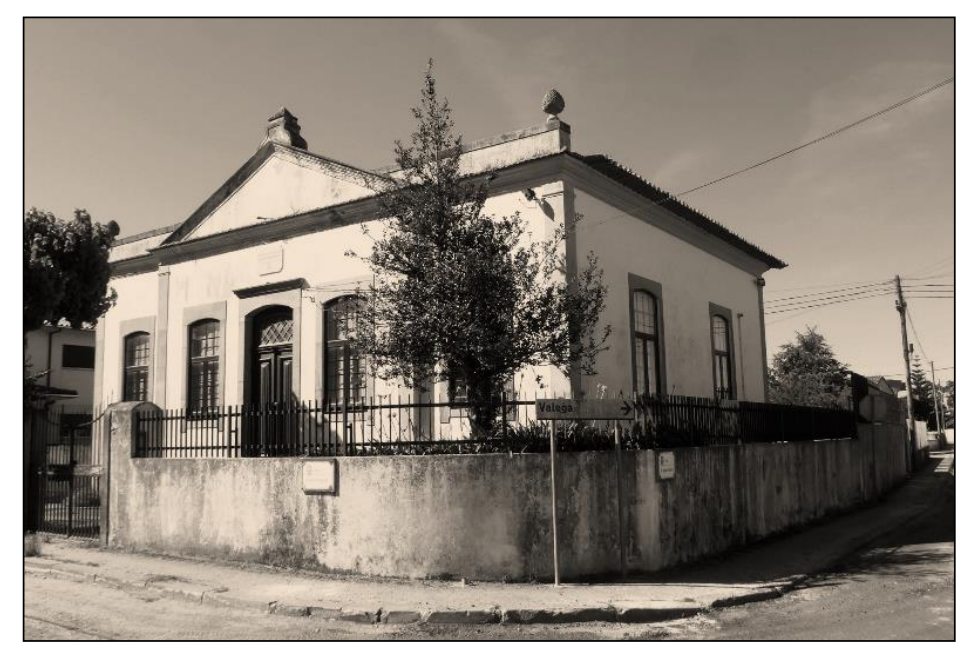

Fonte: Arquivo dos autores.

Figura 2: Detalhe informativo sobre a escola primária para o sexo masculino de São Vicente de Pereira (2014)

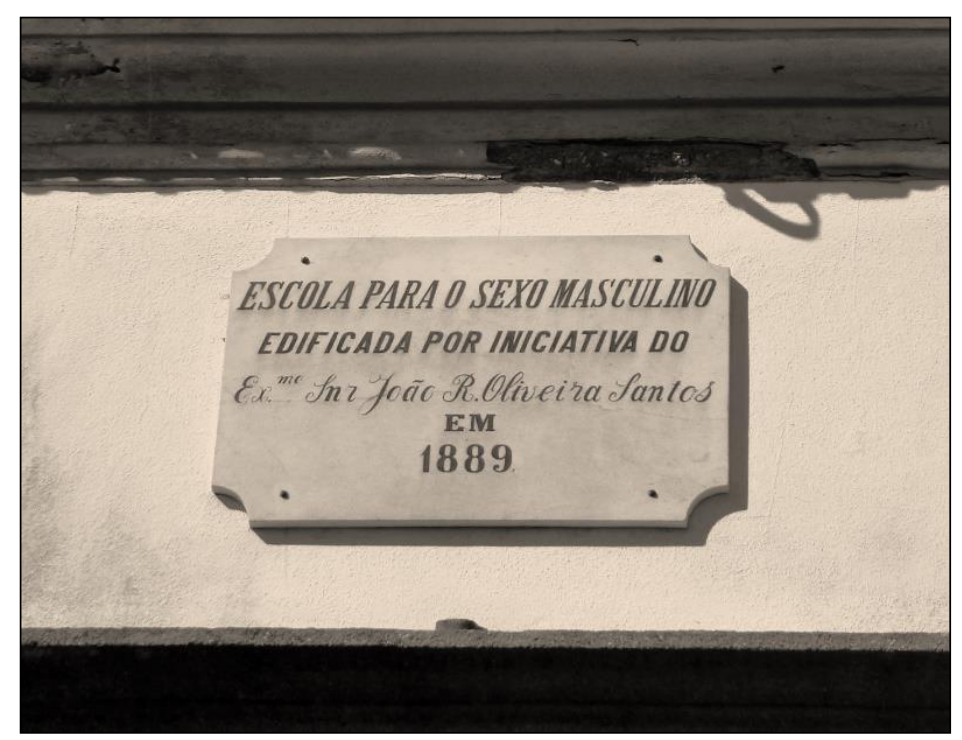

Fonte: Arquivo dos autores.

\section{Considerações finais}

Pretendeu-se com este trabalho, tomando como ponto de partida a construção de um edifício escolar para o sexo masculino, na freguesia de São Vicente de Pereira, município de Ovar, entre os anos de 1888-1892, discutir tanto as atribulações por que passavam as pequenas localidades portuguesas da segunda metade do século XIX, principalmente no que tange às questões instrucionais, como também as relações das paróquias com os municípios e as demais instâncias do Reino, avançando na relação das dificuldades locais com as condições gerais da sociedade e da instrução no mesmo período, acossado por um flagelo que o atingia da paróquia à Corte, $\mathrm{o}$ analfabetismo em alto grau. 
Por meio desse estudo, de caráter local que se abre para o geral, pudemos perceber como as dificuldades orçamentárias, apresentadas pelo poder central para justificar a inexistência ou a falta de continuidade de políticas efetivas em prol da instrução popular, são sentidas com muito maior veemência nas paróquias, como o impasse com que se defronta a freguesia de São Vicente de Pereira ao final do esforço de construção do edifício da escola masculina, impotente frente a um déficit de 144 mil réis, pouco mais do que o salário anual de um professor primário à época. E veja-se que os professores estavam entre os funcionários públicos com pior remuneração, por isso e por sua determinação na condução das crianças no rumo da civilização, foram chamados numa reportagem da imprensa local de "heroes baratos" 42 .

Também se pode perceber a importância do estudo da complexidade burocrática que envolvia a educação portuguesa no passado. A demora para se conseguir todas as aprovações para a execução de uma obra, que deveria passar por múltiplas instâncias, atormentava os administradores paroquiais que, igualmente, precisavam repetir todo o percurso ao final do empreendimento, para comprovar a realização. Isso, se não houvesse qualquer acidente de percurso, a quase inviabilizar a conclusão de alguma iniciativa, como a anulação da venda dos terrenos baldios de São Vicente de Pereira, que deixaram a freguesia, ao final da obra da escola do sexo masculino, em situação de quase falência.

Outro aspecto interessante está ligado ao concurso dos particulares na busca de melhoramentos para as freguesias ou para os municípios, buscando superar tanto a carência da benfeitoria como a falta dos recursos nos cofres municipais ou paroquiais. E para isso muito concorreram os chamados "brasileiros" de torna viagem, que investiram significativamente, principalmente na região Norte de Portugal, em melhoramentos como orfanatos, asilos, hospitais e escolas. Na pequena freguesia de São Vicente de Pereira, o prédio e a mobília para a escola pública das meninas resultou da doação do "brasileiro" João Rodrigues de Oliveira Santos, o mesmo que liderará o processo de recolha de donativos que impulsionou a decisão da Junta de Paróquia de assumir o desafio da construção do prédio da escola para o sexo masculino, dadas as precárias condições em que esta estava a funcionar. Fosse por filantropia, pelo sentimento de responsabilidade para com sua terra natal ou pela busca de reconhecimento social, de respeitabilidade que o dinheiro unicamente não podia assegurar, o certo é que esses personagens marcaram parte das terras portuguesas, tanto em termos materiais, com palacetes e adereços arquitetônicos, como imateriais, ao contribuir para os avanços da instrução e da cultura.

Em suma, muitas são as lições que podemos tirar desse estudo, mas todas confluem para a constatação do atraso instrucional de Portugal no final do século XIX, em relação aos demais países europeus, e para a urgência com que esse problema deveria ter sido enfrentado - o que não ocorreu. Apesar de todos os esforços do Estado, dos municípios, das paróquias e dos privados, Portugal adentrará o século XX com índices de analfabetismo alarmantes para os padrões europeus e ainda levará várias décadas para, finalmente, conseguir disponibilizar uma instrução de massas à sua população.

\section{Referências}

ADMINISTRAÇÃO municipal V. O Povo d'Ovar, 11 de maio de 1890, ano VII, n. 168, p. 1-2.

ALMEIDA, Helder J. de Pinho. A complexidade nos agregados domésticos da freguesia de S. Vicente de Pereira, na $2^{\mathrm{a}}$ metade do século XIX. Dunas, n. 14, novembro de 2014, p. 25-47.

\footnotetext{
${ }^{42}$ O SR. MINISTRO do Reino e os professores primários. O Ovarense, 18 de dezembro de 1892, n. 489, ano X, p. 1.
} 
ALVES, Jorge Fernandes. O "brasileiro" oitocentista e seu papel social. Revista de História, FLUP, v. 12, 1993, p. 257-296.

ARAÚJO, Helena Costa. Precocidade e "retórica" na construção da escola de massas em Portugal. Educação, sociedade \& culturas, n. 5, 1999, p. 161-174.

BENEMERENCIA em favor da instrucção popular. O Ovarense, 8 de julho de 1888 , ano V, n. 262, p. 1-2.

BENEMERITOS. O Ovarense, 10 de junho de 1888, ano V, n. 258, p. 2.

BERNARDO, Manuel. A indústria no concelho de Ovar. Dunas, n. 2, julho 2002, p. 29-36.

CÂMARA Municipal de Ovar. Livro de Actas n. 32, de 12 de Fevereiro de 1887 a 14 de Julho de 1890. Arquivo Municipal de Ovar.

CÂMARA Municipal de Ovar. Livro de Actas n. 33, de 21 de Julho de 1890 a 17 de Julho de 1893. Arquivo Municipal de Ovar.

CANDEIAS, António. Ritmos e formas de alfabetização da população portuguesa na transição de século: o que nos mostram os censos populacionais compreendidos entre os anos de $1890 \mathrm{e}$ 1930. Educação, sociedade \& culturas, n. 5, 1996, p. 39-63.

CANDEIAS, António. Modernidade e cultura escrita nos séculos XIX e XX em Portugal: População, economia, legitimação política e educação. Educação, sociedade \& culturas, n. 31, 2010, p. 146-193.

CONCURSO. O Ovarense, 7 de julho de 1889, ano VI, n. 313, p. 3.

CONTRA a emigração. O Ovarense, 24 de maio de 1891, ano VIII, n. 409, p. 2.

FIDALGO, Joaquim Manoel Monteiro. O ensino na vila de Ovar. A escola da Arruela. Dunas, n. 18 , nov 2018, p. 101-118.

GONÇALVES NETO, Wenceslau; MAGALHÃES, Justino. Ação privada e poder público na luta pela instrução: Portugal na segunda metade do século XIX. Revista Brasileira de História da Educação, n. 20, 2009, p. 15-39.

GONÇALVES NETO, Wenceslau; MAGALHÃES, Justino Pereira de. Luta pela instrução e disputas políticas em Portugal na segunda metade do século XIX: a escola para meninas na freguesia de São Vicente de Pereira, Município de Ovar. Sarmiento, Revista GalegoPortuguesa de História da Educación, v. 23, 2019, p. 51-69. https://doi.org/10.17979/srgphe.2019.23.0.5878

JUNTA de Parochia de S. Vicente de Pereira. Livro de Actas, de 30 de setembro de 1879 a 26 de junho de 1887 [8 de outubro de 1893]. Arquivo da Junta de São Vicente de Pereira.

LAMY, Alberto de Sousa. Monografia de Ovar: Freguesias de S. Cristóvão e de S. João de Ovar, 1865-1916. Vol. 2. Ovar: Câmara Municipal de Ovar, 2001.

MAGALHÃES, Justino. Um contributo para a história do processo de escolarização da sociedade portuguesa na transição do Antigo Regime. Educação, sociedade \& culturas, n. 5, 1996, p. 7-34. 
MAGALHÃES, Justino. Da cadeira ao banco: escola e modernização (séculos XVIII-XX). Lisboa: EDUCA-Unidade I\&D de Ciências da Educação, 2010.

MAIA, Fernanda Paula Sousa. A acção dos "brasileiros" de torna-viagem em Ovar: a obra dos irmãos Oliveira Lopes (Válega). Dunas, n. 5, novembro 2005, p. 3-14.

MANIFESTAÇÃO. O Povo d'Ovar, 29 de julho de 1888, ano III, n. 105, p. 2.

MARTINS, Ernesto Candeias. O ideário da Escola Pública Portuguesa entre os séculos XIX e XX. Montagem, v. 10, 2008, p. 14-41.

MARTINS, Rui. O caminho-de-ferro: veio estruturante da evolução sócio-urbana entre Porto e Aveiro, em exemplo Espinho e Ovar. Dunas, n. 6, novembro de 2006, p. 57-74.

O CAMBIO do Brazil. O Povo d'Ovar, 7 de junho de 1891, ano VIII, n. 213, p. 1-2.

O SERVIÇO telegrapho-postal em Ovar. O Ovarense, 17 de março de 1889, ano VI, n. 298, p. 1.

O SR. MINISTRO do Reino e os professores primários. O Ovarense, 18 de dezembro de 1892 , ano X, n. 489, p. 1.

OS BRAZILEIROS que voltam. O Ovarense, 17 de maio de 1891, ano VIII, n. 408, p. 2-3.

PINHO, João Frederico Teixeira de. Memorias e datas para a vila de Ovar. O Ovarense, 10 de novembro de 1889, ano VII, n. 331, p. 1.

SANTOS, João Rodrigues de Oliveira. Horas Vagas: poesias e prosa. Maranhão [São Luís]: Typ. do Frias, 1868.

SOYSAL, Yasemin Nuhogiu; STRANG, David. Construction of the first mass education systems in nineteenth-century Europe. Sociology of education, n. 62, 1989, p. 277-288. https://doi.org/10.2307/2112831 